HALL RATCLIFFE, A., and JEPSON, R. P. (1950), Four.

Neurosurg, 7.97.
HAMILTON, W. (1947), 'Howell's Textbook of Physiology,' I5th Ed., Philadelphia, Saunders.

HAXTON, H. A. (1949), Brit. Med. Four., 1, 1026.

HERRMAN, L. G., and REID, M. R. (1934), Ann. Surg., 100, 750.

HERZBERG, B. (1926), Arch. f. klin. Chir., 143, 125.

JOSUE, P. (1903), Presse Medicale, 22, 798 .

KATZ, L. N., LINDNER, E., and LANDT, H. (1934), f. Clin.

Invest., 13, 37.
KATZ, L. N., LINDNER, E., and LANDT, H. (1935), Ibid., KOGA, 807 .

Deutsch. Ztschr. f. Chir., 121, 37I.

GH, A. (1922), ' The Anatomy and Physiology of Capillaries,' New Haven, Yale Univ. Press.

LANDIS, E. M., and GIBBON, J. H., Jr. (1933a), Proc. Soc.

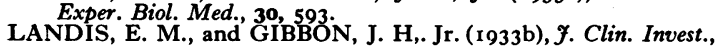
12,925 .

LASKEY, N. F., and SILBERT, S. (1933), Ann. Surg., 98, 55. 80, 66 .

LEWIS, D., and RIECHERT, F. L. (1926), four. Am. Med. Assoc.,

LEWIS, ${ }^{87}$ T., PICKERING, G. W., and ROTHSCHILD, P. (1929), Heart, 15, 359.
LEWIS, T. (1942), 'Pain,' New York, Macmillan.

LILIENTHAL, H. (1907), Ann. Surg., 14, I.

LYONS, R. H. MOE, G. K. NEL̈IGH, R B., HOOBLER S. W., CAMPBELL, K. N., BERRY, R. L., and RENNICK, B. R. (1947), Am. Four. Med. Sci.,213, 315.

MARINESCO, G. (1896), Sémaine Médicale, 16, 65.

MEYER, W. (1925), quoted by BROWN, ALLEN and MAHORNER (1928).

OPPENHEIM, R. (1900), quoted by BUERGER (1924)

van OUWERKERK, L. W. (1946), Ned. Tijdschr. Geneesk, 90, r 362 (abs. World Surg. (1947), 1, 149).

PEARL, F L. (1937), Am. Four. Med. Sci., 194, 505.

SILBERT, S. (1935), Surg. Gynec. Obstet., 6r, 214 .

SMITHWICK, R. H., and WHITE, J. C. (I930), Ibid., 51, 394

SMITHWICK, R. H., and WHITE, J. C. (1935), Ibid., 60, 1 106.

STARR, I. Jr. (1931), Proc. Soc. Exper. Biol. Med., 28, 131.

STEEL, W. A. (1921), Med. Rec. New York, 99, 370.

De TAKATS, G. (1934), Four. Am. Med. Assoc., 103, r9zo.

TELFORD, E. D., and STOPFORD, J. S. B. (I933), Brit. Med. Four.. i, 173.

THOMPSÖN, K. W. (1944), Yale F. Biol. Med., 16, 665.

VEAL, J. R., and MCFETRIDGE, E. M. (1936), Am. Four. Med.

von VINIIWA I I3.

WRIGHT, I. S. (1938), Arch. Phys. Therap., 19, I61.

ZAK, E. (I921), quoted by BUERGER (r924).

\title{
RECENT ADVANCES IN THE TREATMENT OF RHEUMATOID ARTHRITIS
}

\author{
By Geoffrey Loxton, M.B., M.R.C.P.
}

Consultant Physician, Woolwich Group of Hospitals, South-East Region

Since the announcement by Hench and his collaborators at the Mayo Clinic that cortisone (I 7 - hydroxy - I I - dehydrocortico - sterone, Compound E) and ACTH (pituitary adenocorticotrophic hormone) can produce dramatic improvement in patients suffering from rheumatoid arthritis, the medical and lay press have shown a burst of interest in the treatment of this tragic and ancient disease. The general physician and endocrinologist, who in the past were often loath to admit cases to their beds, now all seem keen ' to have a go.' It is therefore important that the problems arising from these new forms of treatment should be viewed with a proper sense of perspective. To do this a brief description of modern views on the aetiology, diagnosis and natural history of the disease is necessary. We must also reconsider our methods of assessing improvement and cure.

\section{Aetiology}

The cause of rheumatoid arthritis is unknown, though most workers agree that heredity and physical or emotional strain may be contributory factors. The disease is commoner in women than in men, in the poor than in the rich, in cold wet climates than in warm dry climates. We shall discuss not only these factors, but also the following suggested causes: focal sepsis, bacterial or virus infection, bacterial or virus sensitivity, vitamin deficiency, endocrinological factors and the general adaptation syndrome of Selye.

Focal sepsis if always sought is not commonly found. Finding and clearing it rarely cures. It 0 cannot therefore be regarded as a constant aetio- $\mathbb{D}$ logical factor.

The disease has many of the characteristics of a chronic infection, fever, malaise, wasting and a 
raised E.S.R., but no bacterium or virus has yet been found which fulfils Koch's postulates.

The evidence that it is a sensitivity state is circumstantial; it is modified by cortisone, which also modifies bacterial sensitivity. Viruses can be reactivated by stress or other disease, as is well exemplified by herpes simplex, and reactivation and sensitivity may go hand in hand.

No vitamin has been shown to effect a cure, though it has been shown that vitamin $\mathrm{C}$ metabolism is altered in rheumatoid arthritis. Vitamin $C$ does not cure rheumatoid arthritis and the disease is not commonly associated with scurvy ; but there is some clinical evidence that it can produce considerable improvement.

The suggestion of Flanders Dunbar and others that it is a psycho-somatic illness tells us little more than that emotional stress may be a causative factor; but psycho-analysis has not proved curative. Whether it has been preventive cannot be proved or disproved. Selye's thesis is that rheumatoid arthritis is one of the diseases of the general adaptation syndrome. Briefly, he suggests that after stress there is a period of adaptation, when there may be an imbalance of mineralo- and glucocorticoid secretion from the adrenal cortex. Among the diseases which he considers may occur during the adaptation period, when there is a relative excess of mineralo-corticoids, e.g. deoxycortone, over gluco-corticoids, e.g. cortisone, are: rheumatoid arthritis, hypertension, periarteritis nodosa, nephrosclerosis, some types of nephritis, appendicitis, gouty arthritis and tonsillitis. He is careful not to deny the microbic theory and states, "it must be kept in mind that the " anti-arthritic effect" of ACTH and cortisone is by no means specifically directed against the hypothetical pathogen which causes rheumatoid or rheumatic joint lesions.'

His brilliant experiments with formalin arthritis in rats confirm this view, but he has only been able to produce arthritis in rats by stress or the administration of deoxycortone inconstantly. Formalin irritation is needed to produce it constantly. This arthritis is improved by cortisone and ACTH and aggravated by deoxycortone.

Hench's statement, 'we find it increasingly difficult to harmonize the microbic theory of the origin of rheumatoid arthritis with the phenomenon of the relief by jaundice or pregnancy' has, perhaps unfortunately, made the theory of endocrine imbalance the most widely held. This endocrine imbalance may of course be inherent or part of the adaptation syndrome; but pathological states developing as the result of infection can be definitely modified by simple changes in endocrine balance; and endocrine imbalance does not eliminate virus or bacterial infection as a possible cause. It must be left for the future to decide whether such substances as cortisone and ACTH are attacking the cause of the disease or altering temporarily the way in which the body reacts to an as yet hypothetical toxic agent.

\section{Diagnosis}

The diagnosis of rheumatoid arthritis rests on the assessment of an easily recognized clinicopathological picture. There is no specific test, such as the Wassermann reaction for syphilis, the blood sugar curve for diabetes or the electrocardiogram for auricular fibrillation. Muscle biopsy, if it proves specific, is a most important step in this direction.

\section{Natural History}

The natural history of the disease without treatment is extremely variable. There may be an acute attack undergoing spontaneous and complete recovery within a few months. This may or may not recur after a period of years, when the disease may run a different course. The disease may progress with natural remissions and exacerbations over many years; or it may progress steadily to complete disability. The extent to which bony and non-reversible disability occurs is also highly variable.

\section{Therapeutic Criteria}

In assessing a therapy for rheumatoid arthritis, the peculiar features of aetiology, diagnosis and natural history already outlined must be kept constantly in mind. The assessment of a therapy must be: does it produce a permanent cure of the reversible part of the disease? If it can do so by a single course of treatment without ill sideeffects, the ideal has been found. If it can do it 
even with continuous administration without sideeffects, it is the next best thing and will be accepted as a therapy in the same way that insulin and diet are for diabetes. There have been numerous attempts to produce therapeutic criteria and one of the best is that adopted by the New York Rheumatism Association in 1949. This report states: ' It becomes important, therefore, to have the period of observation of sufficient length of time to take into account the natural history of the disease.' It suggests an arbitary period of one year and goes on to say: "The ideal specific is an agent which will give lasting arrest of rheumatoid activity in all cases. At the moment there is no such remedy.' At the moment of writing there is still no such remedy.

Owing to the brilliant and painstaking work of Hench and his collaborators over the period of years since 1933 , however, it is now well established that the disease may on occasions undergo spontaneous cure; it may remit during an attack of jaundice, whatever its cause; during pregnancy ; and during the administration of cortisone or ACTH. A year has only just elapsed since the dramatic results produced by these substances were announced. It has become clear that, in doses sufficient to maintain a remission, the sideeffects are so grave that it is impossible to continue the administration of these dynamic drugs indefinitely, and that there is a considerable rebound when treatment is stopped. Thus, by the old criteria which still stand, these substances could not yet be considered as established therapy even were they in sufficient supply; but as Hench has pointed out they are powerful research tools. It has now become essential that we should use not only the old criteria of cure, but should also develop methods of assessing rapid changes in the rheumatoid state which shall take into account spontaneous and psychological factors. Lastly, as cortisone has become a sort of yardstick of this type of change, we must have criteria for assessing if a drug has a cortisone-like action. To avoid some of the confusion of thought that has been apparent in recent literature, it is important that these three conceptions be clearly differentiated. The old and important criteria of cure will not be further di: cussed.

\section{Criteria for Assessing Rapid Changes in the} Rheumatoid State

The assessment of sudden change in the rheumatoid state depends on the measurement of pain, joint tenderness, range of movement both in individual joints and everyday activities, speed and ease of movement, muscular power and, on the pathological side, changes in the E.S.R. Kellgren and his co-workers at the Rheumatic Research Centre, Manchester, have developed methods of measuring joint tenderness, power of grip and joint circulation which are a considerable step forward in this direction. Stanford has demonstrated in a film how cinematography permits subsequent side-by-side comparison of phenomena actually spaced in time. This method is an accurate measure of rapid changes in range, speed and ease of movement both in individual joints and in more complicated manoeuvres.

\section{Criteria for Assessing Cortisone-Like Activity}

These are not yet established either in human beings or animals and until they are finally agree $\phi$ upon it is presumptive to argue from them whether a drug has or has not a cortisone-like action.

It is generally agreed that ACTH produces a fall in the circulating eosinophils, but there is considerable doubt whether cortisone has a similar action, and a recent report from the Mayo Clinic makes it unlikely that it has. Nevertheless some workers have unfortunately been citing it as a criterion of corticoid activity.

The urinary uric acid: creatinine ratio has also been cited as a criterion with perhaps a better foundation in fact. Until the period over which a drug is acting is precisely known and the urine collected accordingly, however, no significance can be attached to reports of these estimations.

In animals, modification of formalin arthritis, bacterial sensitivity, the Arthus's Phenomenon and anaphylaxis are all being studied, but there is no evidence to show that their modification is specific to cortisone-like activity. Seifter has been able to show both in animals and human beings that cortisone will alter the time it takes for a dye injected into a joint space to appear in the urine. This offers still another method of precise assessment. 
It remains to name and give a few details of the drugs that have been under consideration during the past year:

Cortisone. The therapeutic dose is $300 \mathrm{mgm}$. on the first day, followed by $100 \mathrm{mgm}$. daily thereafter. It is given intramuscularly.

ACTH. It is given in divided doses thrice daily by the intramuscular route in doses of $5^{\circ}$ mgm. on the first day and thereafter in $25 \mathrm{mgm}$. doses.

The side-effects of both these drugs which have been mentioned in the literature are Cushing's syndrome, hypertension, diabetes, acute spread of pulmonary tuberculosis, mental disturbance, exacerbation when treatment is stopped, and adrenal atrophy.

Both these substances are at present in such short supply and are so dangerous without proper control that for the present they must be regarded as research tools only.

DeOXYCortone AND Ascorbic ACID. In November 1949 Lewin and Wassen reported from Sweden their original and remarkable observation that a combined injection of deoxycortone and ascorbic acid can produce a dramatic though transitory improvement in the rheumatoid state. The improvement comes on within five minutes and is usually established within half an hour. It lasts from two to six hours and in some cases much longer. There have been reports from numerous workers in different countries confirming this observation. On the other hand, numerous other observers have been unable to confirm the observation. It is difficult to reconcile these differences in observation. Amongst those who have witnessed this phenomenon and done controls to exclude the psychological factor, there is no doubt that it occurs. The confusion of thought referred to when therapeutic criteria were discussed is perhaps responsible for this apparent incongruity. It is an isolated phenomenon that has been reported on and not an established therapy.

So far there have been few reports on the changes in the E.S.R. and the eosinophils. Such reports as have been published do not appear to derive from observations made during the period in which the phenomenon has been reported to occur. The reports so far as they go demonstrate no significant change in the eosinophil count, which, as has already been pointed out, does not argue for or against a cortisone-like action of these substances. In a few of these case reports the E.S.R. appears to have risen significantly between 2 and 24 hours after the combined injection.

The report that deoxycortone and ascorbic acid will modify formalin arthritis in rats does, however, by analogy give some support to the view that they have a cortisone-like action.

The following techniques have been reported as producing this phenomenon:

I. Five mgm. of deoxycortone acetate in oil given intramuscularly, followed within 5 minutes by $\mathrm{I}$ gm. of ascorbic acid intravenously.

2. The two substances given in one syringe intramuscularly.

3. Five mgm. of the water-soluble glucoside of deoxycortone mixed in the same syringe with I gm. of ascorbic acid and given intravenously.

It should be noted that ascorbic acid preparations put up for intravenous work are buffered so that the ascorbic acid is mostly in the form of sodium ascorbate.

This phenomenon appears not to be specific to deoxycortone and ascorbic acid. Hallberg reported an admirably controlled experiment showing that if methylene blue is given instead of ascorbic acid in conjunction with deoxycortone, the phenomenon is also produced. He was also able to show that in some cases methylene blue or ascorbic acid alone produce an effect, though not so pronounced as when combined with deoxycortone. This has been confirmed and even better results reported with sodium thiosulphate than with methylene blue or ascorbic acid. The suggested dosage of both substances is $10 \mathrm{ml}$. of a ro per cent. solution given intravenously. It is also reported that the phenomenon also occurs when three other steroids are substituted for deoxycortone, namely testosterone (25 mgm.), progesterone (4 mgm.) and oestrone $(5 \mathrm{mgm}$.). Ballabio and Sala reported the phenomenon occurring after the use of 21 acetoxypregnenolone with ascorbic acid.

It is too early to speculate yet on how ascorbic 
acid and these steroids produce this phenomenon, but there is evidence to show that the action occurs at the periphery and not via the intermediary of the suprarenal.

Tetraethyl Ammonium Bromide (T.E.A.B.) has been reported as having a beneficial effect on rheumatoid arthritis, the good effect starting between 15 and 30 minutes after injection.

\section{Conclusion}

An attempt has been made to discuss the sig- nificance of the new forms of treatment which have been introduced during the last twelve months. None of them yet fulfils the criteria of a cure or of an established therapy. There is, none the less, great hope that from this tremendous volume of work and interest our knowledge of the fundamental pathology of the disease may increase and a therapy emerge. For the present, however, these methods do not replace the older treatments of rest, physiotherapy and the help of the orthopaedic surgeon.

\section{BIBLIOGRAPHY}

BALLABIO, B. C., SALA, G. (1950), Lancet, i, 644.

BERTHRONG, M., RICH, A. R., GRIFFITH, P. C. (1950), Bull. Fohns Hopk. Hosp., 86, 131.

BROWNLEE, G. ( 1950 ), Lancet, i, 157.

CRANSWICK, E. H., HALL, T. C. (1950), Lancet, i, 540.

CURRIE, J. P., WILL, G. (1950), Lancet, i, 708.

DESMARAIS, M. H. L., GIBSON, H. J., KERSLEY, G. (1948), Ann. Rheum. Dis., 7, No. 3.

DOUTHWAITE, A. H. (1 949), Lancet, ii, 1244.

DUNBAR, F. (r943), 'Psychosomatic Diagnosis,' New York, Paul B. Hoeber.

FLETCHER, E., LUSH, B., BUCHAN, J. F., WOLFF, S. (1950), Lancet, i, 94.

FOX, W. W. (1950), Lancet, i, 135 .

FOX, W. W. (1949), Lancet, ii, 1 I 56.

GORDON, R. G. (1939), Brit. Med. F., i, I 165.

HALLBERG, L. (I950), Lancet, i, 351 .

HARTFALL, S. J., HARRIS, R. (1949), Lancet, ii, 1202.

HENCH, P. (1949), Ann. Rheum. Dis., 8, 97.

HENCH, P. S., KENDALL, E. C., SLOCUM, C. H., POLLEY, H. P. (1949), Proc. Mayo Clin., 24, I81.

HENCH, P. S. (1938), Brit. Med. F., ii, 394.

HEYMAN, F., LEWIN, E., WASSEN, E. (1950), Lancet, i, 642.

HOWELL, T. H. (1950), Lancet, i, 204.

KELLGREN, J. H. (1949), Lancet, ii, 1108.

KERSLEY, G. D., MANDEL, L., JEFFREY, M. R. (1950), Lancet, i, 703.

LANDSBERG, M. (1950), Lancet, i, 134.

LE VAY, D., LOXTON, G. E. (1949), Lancet, ii, I 134.

LE VAY, D., LOXTON, G. E. (1950), Lancet, i, 209.
LEWIN, E., WASSEN, E. (I 949), Lancet, ii, 993.

LLOYD HART, V., STARER, F. (1949), Lancet, ii, 1202.

LONG, D. A., MILES, A. A. (1950), Lancet, i, 492.

METTIER, S. R., GORDON, G. S., RINEHART, G. F., PLUMHOF, C., ELLENHORN, M. J., McBRIDE, A. (1950), Bull. Univ. Calif. Med. Center, r, 337.

McNEE, J. W. (1950), Brit. Med. F., i, x 13.

NASHAT, F. (1950), Lancet, i, 135.

NEW YORK RHEUMATISM ASSOCIATION (1949).

RINEHART, J. F., METTIER, S. R. (r934), Amer. $\mathcal{F}$. Path., ro, 6r.

ROBERTSON, J. A. (1950), Lancet, i, 134.

SEIFTER, J., BAEDER, D. H., BEGANY, A. J. (1949), Proc. Soc. Exp. Biol. Med., 72, 277.

SELYE, H. (1949), The Practitioner, 163, 395.

SELYE, H. (1949), Brit. Med. F., ii, 1129.

SHICK, R. M., BÁGGENSTODD, A. H., POLLEY, H. F. (1950), Proc. Mayo Clin., 25, 135.

SPANOPOULOS, J. A. (1950), Lancet, i, 463.

SPIES, T. D., STONE, R. E., DE MAEYER, E., NIEDERMEIER, W. (1949), Lancet, ii, 1219.

SPRAGUE, R. G., POWELL, M. H., MASON, H. L., ALBERT, A., MATHIESON, D. R., HENCH, P. S., KENDALL, C. W., SLOCUM, C. H., POLLEY, F. H. (1950), Arch. intern. Med., 85, 2, 199.

STANFORD, B., Film 'Rheumatoid Arthritis' (1950), Lancet, i, 675.

ZONDEK, H. (1950), Lancet, i, 5 I 7.

\section{RUTHIN CASTLE, NORTH WALES}

A Clinic for the diagnosis and treatment of Internal Diseases (except Mental or Infectious Diseases). The Clinic is provided with a staff of doctors, technicians and nurses.

The surroundings are beautiful. The climate is mild. There is central heating throughout. The annual rainfall is $\mathbf{3 0 . 5}$ inches, that is, less than the average for England.

The Fees are inclusive and vary according to the room occupied.

For particulars apply to THE SECRETARY, Ruthin Castle, North Wales. 